\title{
Separation of Hemoglobin Types by Cation-Exchange High-Performance Liquid Chromatography ${ }^{1,2}$
}

\author{
SHRI P. GUPTA ${ }^{3}$ AND SAMIR M. HANASH \\ Department of Pediatrics, University of Michigan, Ann Arbor, Michigan 48109
}

Received April 18, 1983

\begin{abstract}
The use of a recently developed cation-exchange HPLC packing material for the separation of hemoglobin types in human blood has been investigated. Adult and newborn hemolysates from normal individuals and from subjects with hemoglobin disorders were analyzed using a weak cation carboxymethyl-bonded phase on 5- $\mu \mathrm{m}$-particle-size silica. Elution was accomplished using a Bistris (2-[bis(2-hydroxyethyl)amino]-2-(hydroxymethyl)-1,3-propanediol) gradient. Seven well-resolved $\mathrm{HbA}_{1}$ fractions eluted before the major $\mathrm{HbA}$ peak. $\mathrm{Hbs} \mathrm{A}_{1 \mathrm{a}}, \mathrm{A}_{1 \mathrm{~b}}, \mathrm{~A}_{\mathrm{lc}}$ and an $\mathrm{HbA}_{1}$ fraction that increased with aging of the hemolysates were separately eluted. HbF when present or when added to the hemolysates eluted as a distinct peak. HbA was followed by $\mathrm{Hbs} \mathrm{A}_{2}, \mathrm{~S}$, and $C$ when present. An early-eluting peak corresponding to Hb Bart's was identified in newborn hemolysates. It is concluded that cation-exchange HPLC provides a new tool for the reliable separation of minor hemoglobin components.
\end{abstract}

Anion-exchange HPLC supports have been utilized to separate hemoglobin types in adult and newborn hemolysates. Good resolution was observed for $\mathrm{HbA}_{2}$ and $\mathrm{HbA}$ variants using anion exchange (1-3). However, $\mathrm{HbF}$, which is present in small quantities in red cells of normal adults, could not be adequately resolved from $\mathrm{HbA}_{1}$ by anion-exchange HPLC. In the past, conventional cation-exchange chromatography has been utilized for the separation of minor hemoglobin types corresponding to modified HbA components. Several cation-exchange HPLC supports have become available recently (4-6). We have therefore investigated the usefulness of cationexchange HPLC for the separation of hemoglobin types in hemolysates from adult and newborn individuals.

\footnotetext{
1 This paper was presented at International Symposium on HPLC of Proteins and Peptides, December 6-8, 1982, Baltimore, Md.

${ }^{2}$ This research project was supported by NIH Grant R01 HL25541.

${ }^{3}$ To whom reprint requests should be addressed.
}

\section{MATERIALS AND METHODS}

Column preparation. A carboxymethylpolyamide cation exchanger was prepared according to the methods described by Gupta et al. (7). HPLC columns measuring $50 \times 4.1$ $\mathrm{mm}$ were packed at 6000 psi for $7 \mathrm{~min}$ and then at 9000 psi for 2 min using a Haskel airdriven fluid pump (Haskel Inc., Burbank, Calif.). All separations were carried out using the same batch of ion exchanger consisting of $5-\mu \mathrm{m}$ silica particles with $300-\AA$ pore diameter.

Sample preparation. Red cells were separated from whole blood by centrifugation and subsequently washed three times with isotonic saline. One volume of cells was lysed with 9 vol of either $0.02 \mathrm{M}$ Tris, $100 \mathrm{mg} /$ liter $\mathrm{KCN}$, pH 8.6, or Bistris ${ }^{4}$ buffer A. Stroma were removed by centrifugation at $11,000 \mathrm{~g}$ for 20 min. Hemolysates were stored at $-20^{\circ} \mathrm{C}$. Ten to forty microliters of hemolysate was injected onto the column for each analysis.

\footnotetext{
${ }^{4}$ Abbreviations used: Bistris, 2-[bis(2-hydroxyethyl)amino]-2-(hydroxymethyl)-1,3-propanediol.
} 
Mobile phase. Buffers were prepared with water obtained from a Milli Super-Q reagentgrade water system (Millipore Corp., Bedford, Mass.). Buffer A, consisting of $0.015 \mathrm{M}$ Bistris, $100 \mathrm{mg} /$ liter $\mathrm{KCN}$, pH 6.0, was utilized for column equilibration. Separation was accomplished using a gradient of buffers $A$ and $B$. The latter consisted of $0.022 \mathrm{M}$ Bistris, $0.3 \mathrm{M}$ $\mathrm{NaCl}, 100 \mathrm{mg} / \mathrm{liter} \mathrm{KCN}, \mathrm{pH} 6.0$.

Chromatographic system. The HPLC system used consisted of two Waters pumps, a Model M-45 and a Model 6000-A, modified with Easy Prime check valves (Waters Assoc., Milford, Mass.). Samples were injected manually or automatically using a Waters Model 710B WISP automatic injector. Gradients were programmed using a Waters 720 system controller. A waters 730 data module recorder/ integrator was used. Absorbance was monitored at $405 \mathrm{~nm}$. Columns were equilibrated for $13 \mathrm{~min}$ between separations, using initial start-buffer conditions of the gradient program at a flow rate of $1.5 \mathrm{ml} / \mathrm{min}$.

\section{RESULTS}

\section{Elution Pattern}

The pattern observed in fresh hemolysates from normal individuals, using a 25-min gradient program with a flow rate of $1 \mathrm{ml} / \mathrm{min}$, included seven peaks which eluted before the major HbA peak (Fig. 1). To determine the identity of the early-eluting peaks, purified hemoglobins $A_{1 a}, A_{1 b}$, and $A_{1 c}$ were obtained by chromatography of diabetic hemolysates on a Bio-Rex column (Bio-Rad, Richmond, Calif.). Each modified hemoglobin was then rechromatographed on the cation-exchange HPLC column either separately or after it was added to a normal hemolysate. A single peak eluting at $10.2 \mathrm{~min}$ was observed with purified $\mathrm{HbA}_{1 \mathrm{c}}$. A peak in the same position was also present in normal (Fig. 1a) and in increased amounts diabetic hemolysates (Fig. 1b). Hemoglobins $A_{1 a}$ and $A_{1 b}$ eluted at 1.9 and 4.5 min, respectively (Figs. $1 \mathrm{a}$ and $\mathrm{b}$ ). The peak eluting at $4.5 \mathrm{~min}$, which amounted to less

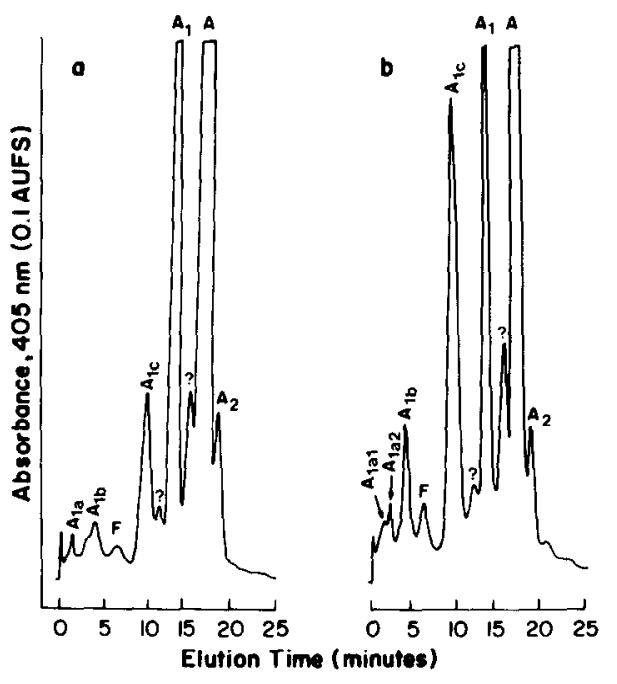

FIG. 1. Cation-exchange HPLC separation of hemoglobins in hemolysates (prepared with Tris buffer, $\mathrm{pH}$ 8.6) from (a) normal adult and (b) diabetic adult, using a 25min gradient program. Sample volume: $10 \mu \mathrm{l}$. Gradient parameters: flow rate, $1 \mathrm{ml} / \mathrm{min}$. Mobile phase at time 0 : $88 \%$ buffer A $(0.015$ M Bistris, $100 \mathrm{mg} /$ liter $\mathrm{KCN}, \mathrm{pH}$ $6.0)$ and $45 \%$ buffer $B$ at $22 \mathrm{~min}(0.022 \mathrm{M}$ Bistris, $0.3 \mathrm{M}$ $\mathrm{NaCl}, 100 \mathrm{mg} /$ liter KCN, pH 6.0). Reequilibration was accomplished by pumping $88 \%$ buffer $\mathrm{A}$ for $13 \mathrm{~min}$.

than $2 \%$ of total hemoglobin, was always observed in normal and diabetic hemolysates. The pattern observed in the first $3 \mathrm{~min}$ of the gradient was variable and frequently included more than one peak. However, the peaks eluting in the first $3 \mathrm{~min}$, either singly or combined, did not amount to more than $3 \%$ of the total hemoglobin. The peak which eluted at 13.2 min corresponded to an $\mathrm{HbA}_{1}$ fraction which increased with aging of the hemolysate when stored over several weeks at $-20^{\circ} \mathrm{C}$. This phenomenon was observed when the hemolysates were prepared with Tris buffer, $\mathrm{pH} 8.6$ (Figs. 1a and b) but not with Bistris buffer, pH 6.0 (Figs. 2a and b). To determine the elution time of $\mathrm{HbF}$, using the 25 -min program, purified $\mathrm{HbF}$ prepared from cord blood was added to adult hemolysates such that $\mathrm{HbF}$ accounted for 1 to $10 \%$ of the total hemoglobin. The peak which eluted at $7.3 \mathrm{~min}$ (Fig. 1) increased in size with increasing concentrations of added HbF. In most hemolysates 


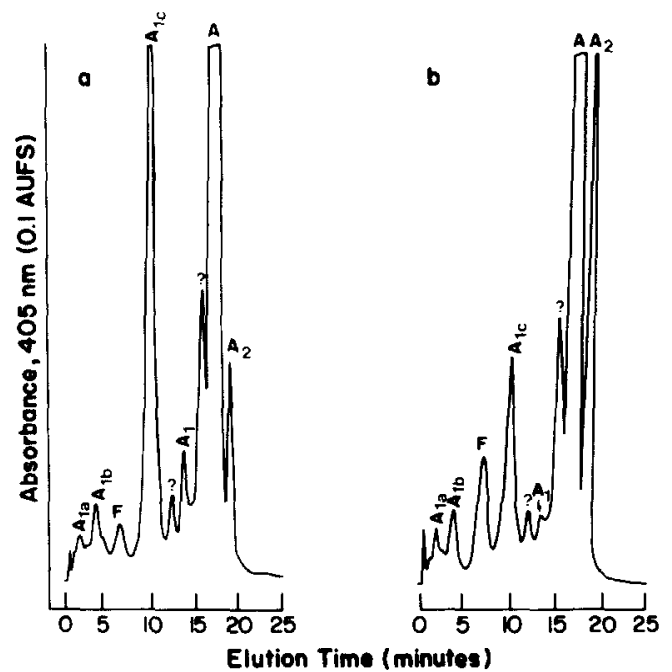

FIG. 2. Chromatographic separation of hemoglobins in hemolysates (prepared with Bistris buffer A) from (a) adult diabetics and (b) an adult with $\beta$-thalassemia and high $\mathrm{HbF}$. Conditions are the same as in Fig. 1.

from normal adults, the $\mathrm{HbF}$ peak accounted for less than $1 \%$ of the total hemoglobin. The remainder of peaks eluting ahead of $\mathrm{HbA}$ have not been identified and probably represent modified $\mathrm{HbA}$.

The peak eluting immediately following $\mathrm{HbA}$ had the same elution time as $\mathrm{HbA}_{2}$ which had been purified by anion-exchange HPLC (2). Although $\mathrm{HbA}_{2}$ was incompletely resolved from $\mathrm{HbA}$, the proportion of this minor hemoglobin in hemolysates from 10 individuals with $\beta$-Thalassemia trait (Fig. 2b) was substantially higher than the amount in hemolysates from normal adults. $\mathrm{HbA}_{2}$ eluted 9 min earlier than $\mathrm{HbC}$ as shown in Fig. 3. It is noteworthy that in hemolysates obtained from individuals with sickle cell anemia or sickle cell trait, the proportion of the peak eluting in the position of $\mathrm{HbA}_{2}$ was much greater than expected based on the proportion of $\mathrm{HbA}_{2}$, indicating coelution of $\mathrm{HbA}_{2}$ with a modified HbS component.

The retention time for $\mathrm{HbA}_{\mathrm{lc}}$ was decreased by increasing the concentration of $\mathrm{NaCl}$ in the start buffer. For example, with $14 \% \mathrm{~B}$ as the initial buffer, $\mathrm{HbA}_{1 \mathrm{c}}$ eluted at $6.5 \mathrm{~min}$ preceded by a $\mathrm{HbF}$ peak at $4.7 \mathrm{~min}$ (Fig. 4a).

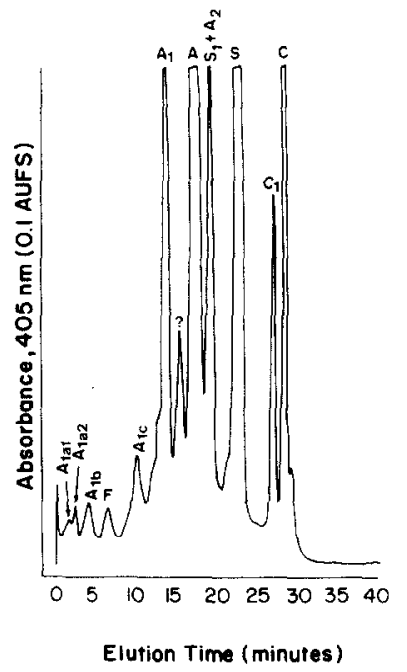

FIG. 3. Chromatographic separation of hemoglobins in hemolysates from an adult with SC disease who has been transfused using a $30-\mathrm{min}$ gradient program. Conditions are the same as in Fig. 1, except $55 \%$ buffer $B$ at $30 \mathrm{~min}$.

However, with further increases in salt concentration in the start buffer, $\mathrm{HbF}$ and $\mathrm{HbA}_{\mathrm{Ic}}$ are not well resolved from each other (Fig. 4b).

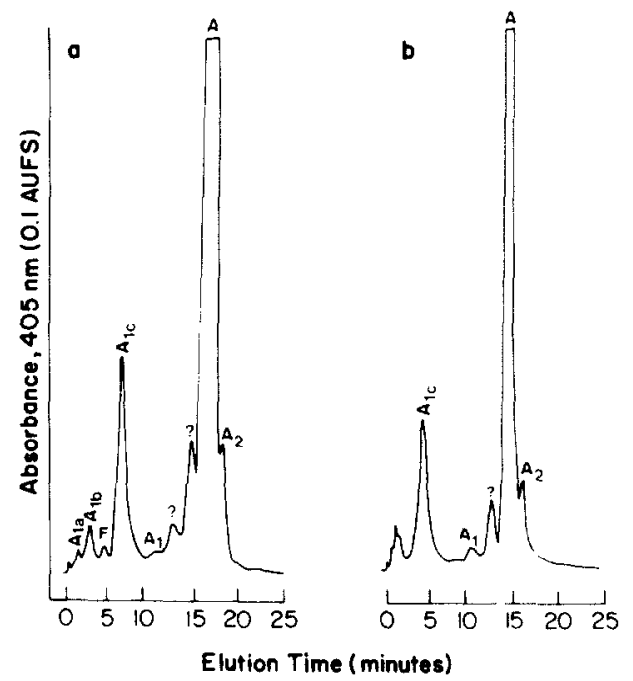

FIG. 4. Chromatographic separation of hemoglobins in hemolysates (prepared with Bistris buffer $\Lambda$ ) from a diabetic adult. Conditions are the same as in Fig. 1 except (a) mobile phase at time $0: 86 \%$ buffer $A$ and $45 \%$ buffer B at 22 min. (b) Mobile phase at time $0: 84 \%$ buffer $A$ and $45 \%$ buffer $B$ at $20 \mathrm{~min}$. 
Cord blood hemolysates were also analyzed by cation-exchange HPLC. Using a 25 -min gradient with $10 \% \mathrm{~B}$ as the initial starting buffer, $\mathrm{Hb}$ Bart's eluted as a nonretained peak at $0.9 \mathrm{~min}$, followed by two pcaks cluting at 6.5 and $8.7 \mathrm{~min}$ corresponding to modified $\mathrm{HbF}$ as shown in Fig. 5. The major HbF peak eluted at $12.0 \mathrm{~min}$ followed by $\mathrm{HbA}$ which eluted at $18.0 \mathrm{~min}$. However, using a 35 -min gradient, with $100 \% \mathrm{~A}$ as the starting buffer, $\mathrm{Hb}$ Bart's was retained longer and eluted at $7.2 \mathrm{~min}$ as shown in Fig. 6a. The identity of the $\mathrm{Hb}$ Bart's peak was determined by rechromatography of the corresponding fraction on a reverse-phase $\mu$ Bondapak $\mathrm{C}_{18}$ column (8). Two $\gamma$-chain peaks corresponding to $G$ and A globin were observed. The peaks that eluted at 6.5 and $8.7 \mathrm{~min}$ (Fig. 5) were individually rechromatographed on an anion-exchange HPLC column (2) and were found to correspond to $\mathrm{HbF}_{11}$ and $\mathrm{HbF}_{1}$, respectively.

We have evaluated the extent of variability in the chromatographic pattern between columns. For columns prepared from the same batch of ion exchanger, the retention time for any given hemoglobin type did not vary by more than $0.3 \mathrm{~min}$. Greater variability in retention was observed between columns pre-

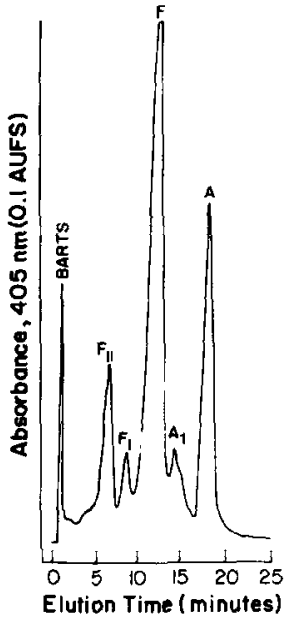

FIG. 5. Chromatographic separation of hemoglobins in a hemolysate (prepared with Bistris buffer A) from a newborn with $\alpha$-thalassemia. Conditions are the same as in Fig. 1, except mobile phase at time $0: 90 \%$ buffer $A$ and $40 \%$ buffer $B$ at $25 \mathrm{~min}$.

pared from different batches. However, the overall chromatographic pattern did not change appreciably. Increasing the column length from 5 to $10 \mathrm{~cm}$ also did not have any appreciable effect on resolution. Deterioration in column performance was observed after approximately $1000 \mathrm{~h}$ of use. This was asso-

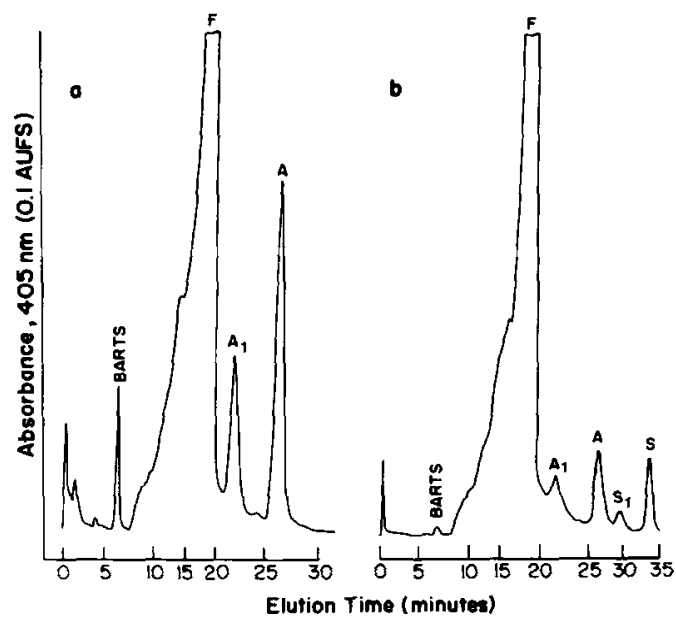

FIG. 6. Chromatographic separation of hemoglobins in hemolysates (prepared with Tris buffer, pH 8.6) from two newborns, (a) $\alpha$-thalassemia and (b) sickle cell trait, using a 30-min gradient program. Other conditions are the same as in Fig. 1. Mobile phase at time 0: $100 \%$ buffer A; $5 \%$ buffer B in $0.3 \mathrm{~min} ; 10 \%$ buffer $B$ at $0.8 \mathrm{~min}$; and $52 \%$ buffer $B$ at $35 \mathrm{~min}$. 
ciated with an increase in back pressure and column voiding.

\section{DISCUSSION}

The results obtained indicate that under optimal conditions, cation-exchange HPLC provides excellent separation of modified $\mathrm{HbA}$ components in adult blood. Previously, conventional cation exchangers, particularly BioRex 70, were found to be useful for the separation of modified hemoglobins including $\mathrm{HbA}_{1 \mathrm{c}}(9,10)$. The silica-based packing material we have utilized presents several advantages over conventional cation exchangers. Silica particles pack tightly because of their spherical shape whereas conventional exchanges, being mostly nonspherical, pack irregularly. As a result, sharper chromatographic peaks are observed with silica-based material. Silica particles can tolerate high pressure and high flow rates without compression of the chromatographic bed. Conventional exchangers are susceptible to $\mathrm{pH}$ and salt concentration which affect particle size. The separation time using the cation exchanger we have developed is therefore predictably shorter than with conventional chromatography. Resolution is further improved with the use of small silica particles which allow tighter packing, thus reducing the extent to which solute molecules would follow multiple paths.

A major improvement in resolution is demonstrated by the ability to separate $\mathrm{HbF}$ from $\mathrm{HbA}_{1 \mathrm{c}}$, thus allowing the detection of small amounts of $\mathrm{HbF}$ in adult blood and possibly improving the reliability of $\mathrm{HbA}_{1 c}$ quantitation. Accurate measurements of $\mathrm{HbA}_{1 \mathrm{c}}$ levels are of relevance not only to diabetes but also to the estimation of red cell survival (11).

$\mathrm{HbA}_{2}$ is not as well resolved from $\mathrm{HbA}$ by cation-exchange as with anion-exchange HPLC $^{2}$. However, one advantage of the cation-exchange system is the separation of $\mathrm{HbA}_{2}$ from $\mathrm{HbC}$. Further improvement in the cation-exchange HPLC program would be needed for baseline resolution of $\mathrm{HbA}$ and $\mathrm{HbA}_{2}$. Furthermore, care must be taken in the interpretation of the proportion of $\mathrm{HbA}_{2}$ in the presence of $\mathrm{HbS}_{1}$, since a $\mathrm{HbS}_{1}$ fraction coelutes with $\mathrm{HbA}_{2}$.

The separation of hemoglobins in cord blood hemolysates required modification of the buffer conditions to allow retention of the early-eluting fractions. Adequate separation of Hb Bart's was achieved by using $100 \%$ buffer A for column equilibration and for the start of the gradient. Hb Bart's fractions comprising less than $0.5 \%$ of the total hemoglobins were readily detected suggesting that the cation HPLC system could be useful for the diagnosis of $\alpha$-thalassemia.

The ability to separate $\mathrm{HbF}$ and modified hemoglobins, coupled with the reproducibility, sensitivity, and automation of HPLC, suggests that the cation-exchange approach we have developed could be an important new tool for the diagnosis of disorders involving hemoglobin.

\section{REFERENCES}

1. Hanash, S. M., and Shapiro, D. N. (1980) Hemoglobin 5(2), 165-175.

2. Amanullah, A., Hanash, S., Bunnell, K., Strahler, J., Rucknagel, D., and Ferruci, S. (1982) Anal Biochem. 123, 402-407.

3. Huisman, T. J. H., Gardiner, M. B., and Wilson, J. B. (1981) Advances in Hemoglobin Analysis (Hanash, S. M., and Brewer, G. J., eds.), pp. 6982, Alan R. Liss, New York.

4. Schifreen, R. S., Hickingbotham, J. M., and Bowers, G. N. (1980) Clin. Chem. 26, 466-472.

5. Umino, M., Watanabe, H., Komiya, K., and Mori, N. (1981) in International Symposium on the HPLC of Proteins and Peptides, Washington, D. C., Paper No. 208.

6. Mikes, O., Sedlackova, J., Rexova-Benkova, L., and Omelkova, J. (1981) J. Chromatogr. 207, 99-114.

7. Gupta, S., Pfannkoch, E., and Regnier, F. E. (1983) Anal. Biochem. 128, 196-201.

8. Henson, J. B., Carver, J. R., Wilson, J. B., and Huisman, T. H. J. (1980) J. Chromatogr. 198, 443448.

9. Cole, R. A., Soeldner, J. S., Dunn, P. J., and Bunn, H. F. (1978) Metabolism 27, 289-301.

10. McDonald, M. J., Shapiro, R., Bleichman, M., Solway, J., and Bunn, H. F. (1978) J. Biol. Chem. 253. 2327-2332.

11. Panzer, S., Kronik. G., Lechner, K., Bettelheim, P., Neumann, E., and Dudczak, R. (1982) Blood 59, 1348-1350. 